\title{
Development of Smartphone Application to Measure Accumulated Sound Pressure Levels
}

\author{
Jihun Shin', Gibbeum Kim², Woojae Han ${ }^{3}$, Changgeun Song ${ }^{4}$ \\ 'Department of Convergence Software, Graduate School, Hallym University, Chuncheon, Korea \\ ${ }^{2}$ Department of Speech Pathology and Audiology, Graduate School, Hallym University, Chuncheon, Korea \\ ${ }^{3}$ Division of Speech Pathology and Audiology, Research Institute of Audiology and Speech Pathology, College of Natural Sciences, Hallym University, \\ Chuncheon, Korea \\ ${ }^{4}$ Department of Convergence Software, College of Information and Electronic Engineering, Hallym University, Chuncheon, Korea
}

\author{
누적 청취 음량 측정을 위한 스마트폰 어플리케이션의 개발 \\ 신지훈 ${ }^{1} \cdot$ 김기쁨 ${ }^{2} \cdot$ 한우재 $^{3} \cdot$ 송창근 $^{4}$ \\ 한림대학교 일반대학원 융합소프트웨어학과 ${ }^{1}$, 한림대학교 일반대학원 언어병리청각학과 ${ }^{2}$, \\ 한림대학교 자연과학대학 언어청각학부· 청각언어연구소 ${ }^{3}$ 한림대학교 정보전자공과대학 융합소프트웨어학과 ${ }^{4}$
}

\begin{abstract}
Purpose: Although it is acknowledged that abuse of portable listening devices such as high level of volume and long duration possibly occurs noise-induced hearing loss to young adults, there is no tool to accurately measure their levels and time duration. The present study aimed to develop a smartphone application which estimated user's volume levels, the accumulated levels, and exposure time when he/she listened to music. Methods: The application which mainly consisting of service and activity was developed for Android users. Service function worked for measurement and transmission of data in the back, whereas the activity function with main activity and fragment took charge of various screen displays in the front. In addition, all data of application users was sent to a server system having Apache, Hypertext Preprocessor, My Structured Query Language and saved in real time. Finally, accuracy and reliability of the application was proved by using sound level meter and artificial ear simulator system. Results: The developed application had measurement image and data image. For the measurement image, image bar, option bar, graph view, text view, and seek bar were displayed during the listening to music. Data image presented four graphical views by time, daily, weekly and monthly and a calendar view with three different color codes. All data was saved at every five seconds in the main server system. Conclusion: Although preliminary data was run by three subjects to fully confirm any component for malfunction of the application, no problem was found. If applying further clinical study with a large size of participants, we expect that the application will be very helpful for the users to prevent themselves from hearing insult induced by high levels of music and long exposure time.
\end{abstract}

Key Words: Smartphone application, Sound pressure levels, Earphone, Noise-induced hearing loss, Android.

Received: September 19, 2017 / Revised: September 30, 2017 / Accepted: October 11, 2017

Correspondence: Changgeun Song, Department of Convergence Software, College of Information and Electronic Engineering, Hallym University, 1 Hallimdaehak-gil, Chuncheon 24252, Korea

Tel: +82-33-248-2317 / Fax: +82-33-242-2524 / E-mail: cgsong@hallym.ac.kr

\section{INTRODUCTION}

산업 기술의 발달로 인해 현대인의 삶은 보다 편리해졌으나, 기계를 사용하는 과정에서 발생되는 과도한 소음은 청력을 손 실 시키는 등 현대인들에게 부정적인 영향을 주고 있다(Kim, 2003). 특히, 스마트폰의 광범위한 보급 및 확산으로 인해 현대 인들은 일상생활 속에서 별도의 음향기기의 구매 없이도 자체 내장된 MP3 플레이어 기능을 활용한 음악 청취 및 동영상 시청
이 용이해졌다. 그러나 음악 청취 시 일정 강도 이상의 볼륨으로 고강도의 소리에 지속적으로 노출됨에 따라 무분별한 음악 청 취는 현대인의 소음성 난청 발병율을 증가시키고 있으며, 추후 이들의 노인성 난청 또한 조기화시키고 있다(Kujawa \& Liberman, 2009).

고강도의 소음 노출로 인해 발생되는 청력 손실은 노출 양상 에 따라 크게 세 가지로 분류될 수 있다. 첫째, 일시적 역치변동 (temporary threshold shift)은 중등도 크기의 소음 노출로 인해 
발생하는 일시적인 청력 손실로 주로 $3 \sim 6 \mathrm{kHz}$ 에서 특징되며, 수분에서 수일에 걸쳐 청력이 회복된다. 둘째, 일시적 역치 변동 후 회복 기간 내 추가적인 소음 노출 없이 청력이 3주 내에 회복 되지 않을 경우 영구적 역치 변동(permanent threshold shift)으 로 간주한다(Ryan et al., 2016). 셋째, 폭발음과 같이 $120 \mathrm{~dB}$ (A) 이상의 강력한 소음 노출로 인해 발생하는 청력 손실은 음향성 외상(acoustic trauma)이라 정의한다. 음향성 외상은 고막과 이 소골 등의 중이 구조물은 물론 난원창막, 정원창막, 코르티기관 을 포함한 내이 구조물들의 기계적 손상을 발생시키고(Axelsson \& Hamernik, 1987), 개막의 수축과 지지세포 표면의 확장 및 손실과 같은 신경학적 변화를 야기시킨다(Saunders et al., 1985). 뿐만 아니라, 과도한 소음 노출로 인해 부차적으로 발생 하는 신체적·정신적 부정적인 영향들이 학계에서 지속적으로 보고되고 있다(Basner et al., 2014; Kim, 2003). 즉, 소음성 난 청으로 인한 두통, 불안감, 수면 장애, 심장 질환, 인지적 결함 및 소화 기관의 장애 등의 비청각적 문제들이 현대인의 삶 속에 부 정적으로 나타나고 있다(Basner et al., 2014).

따라서 소음성 난청으로 인한 이러한 문제들을 진단하고 대 처하기 위한 정확한 실태조사가 요구되나, 현재까지 출간된 다 수의 국내외 연구들은 실제로 노출된 사용자의 청취 음량을 측 정하기보다는 이어폰 종류에 따른 음압강도의 비교 혹은 휴대 용 음향기기의 사용 실태, 선호 볼륨 단계 및 소음성 난청의 인 식에 대한 설문조사가 주를 이루고 있는 실정이다(Keppler et al., 2015). Danauer et al.(2009)은 대학생들의 여가활동 시간 및 휴대용 음향기기의 사용 시간에 대한 설문조사를 진행한 결과, 응답자의 38.9\%가 하루 1 2시간 동안 주로 7단계(24.8\%) 와 6단계(20.9\%)의 볼륨 단계를 사용하는 것으로 나타났다. 또 한 응답자의 $76 \%$ 가 이어버드형 이어폰을 사용하는 것으로 보 고되었으며, 이러한 타입의 이어폰은 주변의 배경 소음을 차단하 지 못하기 때문에 음악 청취 시 사용자가 일정 이상의 큰 볼륨 에 노출될 위험성이 있다(Filgor \& Cox, 2004; Hodgetts et al., 2007). 또한 고등학생 및 성인을 대상으로 설문조사를 실시한 Zogby International(2006)의 연구와 이어버드형 이어폰의 객 관적 음압강도를 측정하고 주변 배경 소음에 따른 선호음량을 조사한 Williams(2005)의 연구 모두 대부분의 사용자들이 안 전한 볼륨 수준에서 음악을 청취하지만, 배경 소음이 높아짐에 따라 스스로 의식하지 못한 채 청취 음량의 볼륨을 높이는 경 향이 두드러졌다. Hodgetts et al.(2007) 연구 역시 정상 청력을 지닌 대학생 총 38 명을 대상으로 이어폰 종류와 조용한 환경 및 다양한 배경 소음이 존재하는 상황에서 선호 청취 음량을 조사한 결과, 일반적으로 조용한 환경보다 배경 소음이 있는 환경에서 더 큰 음량으로 청취하는 것으로 나타났으며, 이에 따라 사용자에게 소음성 난청이 유발될 가능성이 상승한다고
경고하였다. 한편, Spieth \& Trittipoe(1958)가 소음의 노출 강도 뿐만 아니라 소음에 노출되는 시간 또한 청력 손실과 높은 연관 성을 보인다고 함에 따라, Hodgetts et al.(2007)은 하루 허용 소 음 노출 $100 \%$ 에 도달하는 시간을 소음성 난청 기준에 적용하 여 계산하였고(NIOSH, 1998), 최소 3시간에서 최대 77시간까 지 청취 시간이 허용 가능하였으나 배경 소음이 높아질수록 허 용 시간이 뚜렷이 감소되어야 함을 결론 내렸다.

종합해보면, 국내외의 기존 연구들은 이어폰의 종류에 따른 음압 강도 비교, 휴대용 음향기기 사용 실태에 대한 설문조사 등의 연구가 주를 이루고 있다. 이러한 관련 연구들로 인해 휴대 용 음향기기의 무절제한 사용과 그로 인한 소음성 난청의 위험 성에 대한 인식이 어느 정도 환기될 수 있으나, 실생활 속에서의 휴대용 음향기기의 사용패턴에 대한 구체적인 연구는 부재하다. 즉, 이어폰을 통한 MP3 플레이어 사용 시, 사용자가 실제 청취 하는 음악의 강도 및 사용시간에 대한 실질적이고 객관적인 평 가와 분석이 이루어지고, 이를 통해 소음성 난청의 유발 가능 성을 예측할 필요가 있다. 구체적으로, 휴대용 음향기기 사용자 들이 청력 손실이 유발되지 않는 정도의 안전한 볼륨 수준으로 청취하고 있는지, 혹은 주변 배경 소음 증가에 따라 선호하는 볼륨이 어느 정도 증가하는지 등 실생활 속 사용패턴이 반영된 현실적인 결과를 얻기 위한 객관적인 추적 실험을 시행할 필요 가 있으며, 이를 바탕으로 소음성 난청을 예방하기 위한 보다 과학적인 근거가 요구되고 있다. 이를 반영하여 본 연구에서는 사용자가 이어폰을 통해 듣는 선호 청취 음량의 평균 강도 및 최고 강도에 대한 정보를 추적 조사하기 위한 목적에서 스마트 폰 어플리케이션을 개발하고, 추후 이를 바탕으로 사용자들의 노출 음량 강도를 분석하고 적절한 청취 및 휴식의 필요성을 제고함으로써 궁극적으로는 소음성 난청의 예방에 기여하고자 한다.

\section{MATERIALS AND METHODS}

\section{어플리케이션의 구성}

어플리케이션 개발을 위해 안드로이드 어플리케이션 개발의 통합개발환경을 제공하는 도구인 Android Studio 2.2.1과 안드 로이드 소프트웨어 객체지향언어(Java Development Kit, JDK; Oracle, San Francisco, CA, USA) 1.8.0_66b-18 amd 64를 기 반으로 Android Software Development Kits (SDK, ver. 5.1.1 및 ver. 4.4.2, Google, Mountain View, CA, USA)를 적용하였 다. 본 어플리케이션은 안드로이드 스마트폰에 연결된 이어폰 을 통해 출력되는 음원의 평균 강도(LZeq), 최고 음압 강도 (LCpeak), 배경 소음 강도(dB SPL)를 측정하여 데이터 베이스 에 저장하고, 저장된 데이터는 일별/주별/월별로 사용자가 청 
취한 음량을 분석하도록 구성하였다. 즉, 음원의 평균 강도는 $\mathrm{mp} 3$ 혹은 wav 등의 음악 파일이 재생될 때 이어폰을 통해 나 오는 음압을 $\mathrm{dB}$ SPL로 수치화하여 사용 시간으로 나누었고, 최고 음압 강도는 해당 시간(이어폰이 작동하여 실행해서 멈추 는 시간까지)에 가장 높았던 $\mathrm{dB} \mathrm{SPL}$ 을 수치화하였다. 이는 기존 소음측정계와 동일한 알고리즘을 적용하였다(NIOSH, 1998). 또 한 저장된 데이터는 사용일자를 기준으로 사용자 각자의 실제 노출량을 실시간으로 분석한 후 그래프와 텍스트 형식으로 표 기하여 사용자가 이해하기 쉽도록 설계하였다.

\section{어플리케이션의 설계}

어플리케이션은 크게 Service와 Activity로 구성하였다. Service는 어플리케이션의 디스플레이 여부와 상관없이 무한히 실 행되는 컴포넌트로서 데이터 측정과 데이터 전송을 담당한다. Activity는 어플리케이션의 디스플레이 역할을 하며, 크게 Main Activity와 Fragment로 구성된다. 각각의 구체적인 구성 및 역할은 Figure 1과 같다.

\section{Service}

Service는 측정 및 보정 부분과 이어폰 연결의 유무 부분으 로 구성하였다. 구체적으로 사용자가 듣고 있는 음량의 측정과 보정, 이어폰 연결의 유무 확인, 컴포넌트 통신, 서버 통신을 담 당하였다. 또한 Sampling Meter는 음량 측정, 데이터 보정, 전
송 및 정지 기능을 담당하였다. 측정 기능의 경우, 실제 안드로 이드에서 이어폰으로 출력되는 음량 데이터를 측정하며, 데이 터 보정은 이어폰에서 출력되는 음량과 안드로이드에서 출력 하는 음량 데이터 값의 차이를 보정하고 현재 볼륨 단계 값을 계산하였다. 이어폰 연결의 유무 확인은 안드로이드의 이어폰 연결 상태를 확인하는 부분이다. 마지막으로 컴포넌트 통신은 Service에서 측정한 음량 데이터를 Activity로 전송하는 부분 이고, 서버 통신은 측정된 음량 데이터를 실시간으로 서버로 전 송하는 부분이다. 사용자의 데이터는 1 초 간격으로 측정하였 고, 5 초 단위로 통신하도록 설정하였다.

\section{Activity}

Activity는 안드로이드의 전체적인 화면 구성을 담당하고, Background Service를 실행하는 역할을 하였다. 또한 하위 Fragment를 관리하며 Fragment 간 이동을 담당하였다. 개발된 어플리케이션의 Activity는 1개의 Main Activity로 구성하였고, 하위 Fragment들의 이동을 위하여 탭 뷰를 사용하였다. 각 탭 은 헤드폰, 그래프, 달력, 설정 이미지로 구성하였다.

(1) Main Activity

Main Activity는 Activity와 Fragment를 총 관리하며 Service 를 시작하는 역할과 Intent를 통해 통신하는 역할을 맡았다. Main Activity의 화면은 옵션 바와 이미지 바 두 개로 구성하 였고, 하위 Fragment는 4개로 설정하였다. 서비스 시작은 Ac-

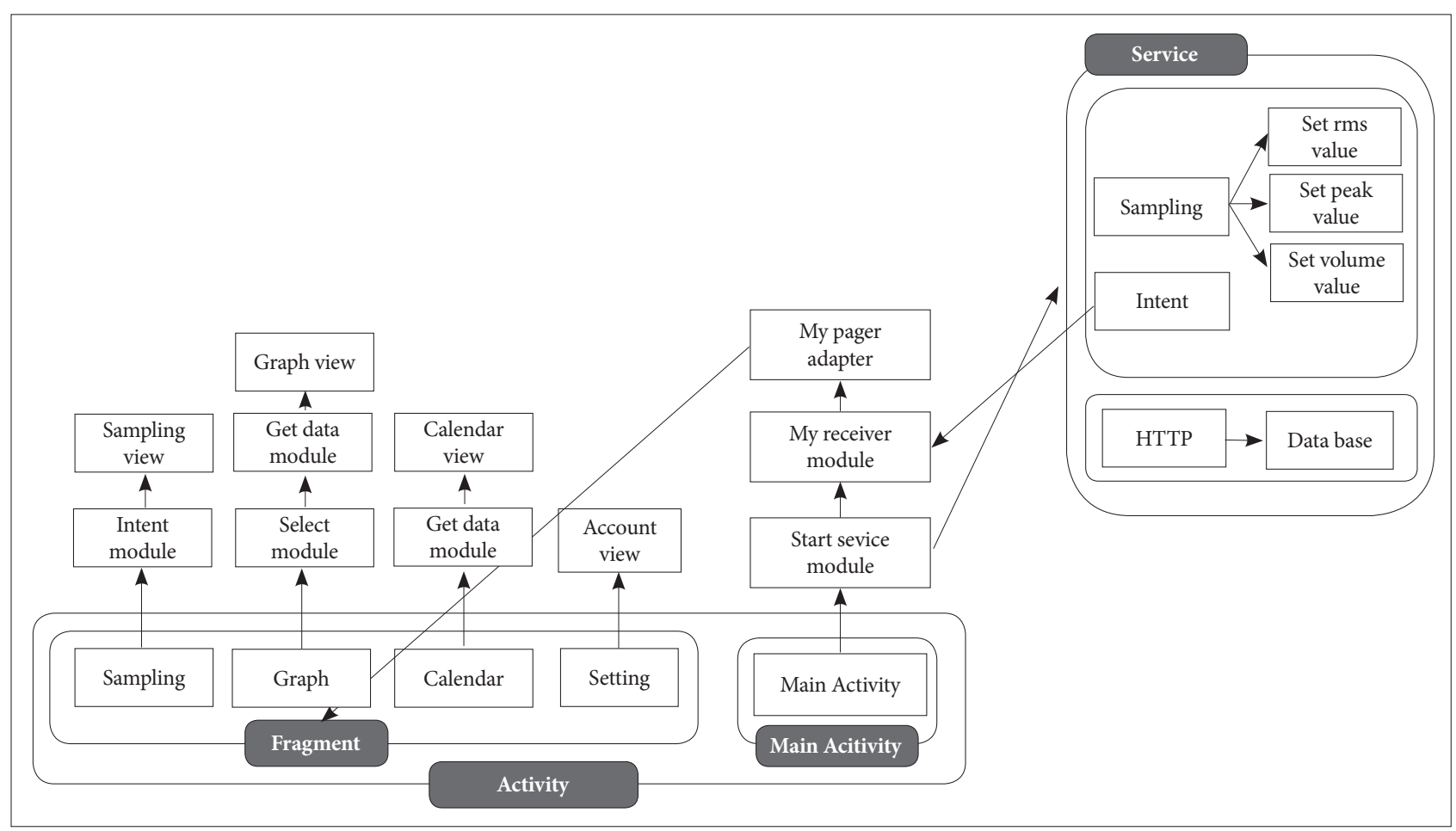

Figure 1. A flow chart of developed Android application. 
tivity가 활성화되면, 자동 시작하도록 구성하였다. Service에서 측정되는 음량들은 Intent를 통해 수신하고, 그 값들을 실시간 으로 Sampling Fragment로 전송하여 화면에 출력하도록 하였 다. 또한 사용자들을 구분하기 위해 사용자의 계정 정보를 서버 에 등록시키도록 하였다. 즉, Main Activity에서 사용자를 자동 으로 구분하여 서버 시스템에 사용자 정보를 전송하며, 서버 등 록 여부를 확인하고 등록하는 역할을 하였다.

(2) Fragment

Fragment 컴포넌트는 Activity의 하위 개념으로 한 개의 Activity에서 여러 개의 화면으로 구성할 수 있도록 해주는 컴 포넌트이다. 본 어플리케이션은 현재 측정값들을 확인할 수 있 는 Sampling Fragment, 현재까지 측정된 값들을 그래프로 확 인할 수 있는 Graph Fragment, 사용자의 측정값을 토대로 위 험군에 속하는지 알려주는 Calendar Fragment, 사용자의 계 정 정보를 확인할 수 있는 Setting Fragment로 구성하였다.

\section{서버 시스템의 설계}

서버 시스템은 Apache (server system), Hypertext Preprocessor (PHP), My Structured Query Language (MySQL)의 Application Performance Management가 설치되어 있는 서버 PC 를 뜻한다. 서버 시스템은 크게 데이터 수신 부분과 전송 부분 으로 구성하였다. 데이터 수신 부분은 클라이언트 시스템에서 전송한 데이터들을 실시간으로 수신하고 저장하도록 구성하였 고, 데이터 전송 부분은 클라이언트 시스템에서 요청한 데이터 를 요청 데이터 형식에 맞게 조회하여 클라이언트 시스템으로 전송하였다(Figure 2).
Apache 서버

Apache 서버는 클라이언트 시스템과 서버 시스템의 PHP 페 이지를 연결해주는 서버로, 클라이언트 시스템에서 요청한 부 분을 PHP 페이지로 연결해주는 역할을 하였다. 클라이언트 시 스템과 서버 시스템의 모든 통신을 Apache 서버를 통해 연결 하였다.

MySQL

데이터를 저장 관리하기 위해서 필요한 데이터베이스 시스템 은 MySQL을 사용하였고, 각각의 데이터를 저장하기 위해서 Table 1과 같이 구성하였다. 또한 여러 데이터들의 충돌을 방지 하기 위하여 사용자 1 인당 1 개의 테이블을 각각 생성하였으며, 사용자를 구분하기 위하여 테이블 이름은 사용자의 구글 계정 의 아이디로 설정하였다.

\section{어플리케이션의 신뢰성 확인}

개발된 안드로이드용 스마트폰 누적 청취 음량 어플리케이션 이 연결된 이어폰을 통해 재생될 시 볼륨 단계에 따라 음원의

Table 1. Table display for configuring database

\begin{tabular}{cc}
\hline Column name & Date type \\
\hline AVGSPL & Double \\
PEAKSPL & Double \\
Volume & Intent \\
User & Varchar $(255$ byte $)$ \\
Time & Date time \\
\hline
\end{tabular}

AVGSPL: average sound pressure level, PEAKSPL: peak sound pressure level

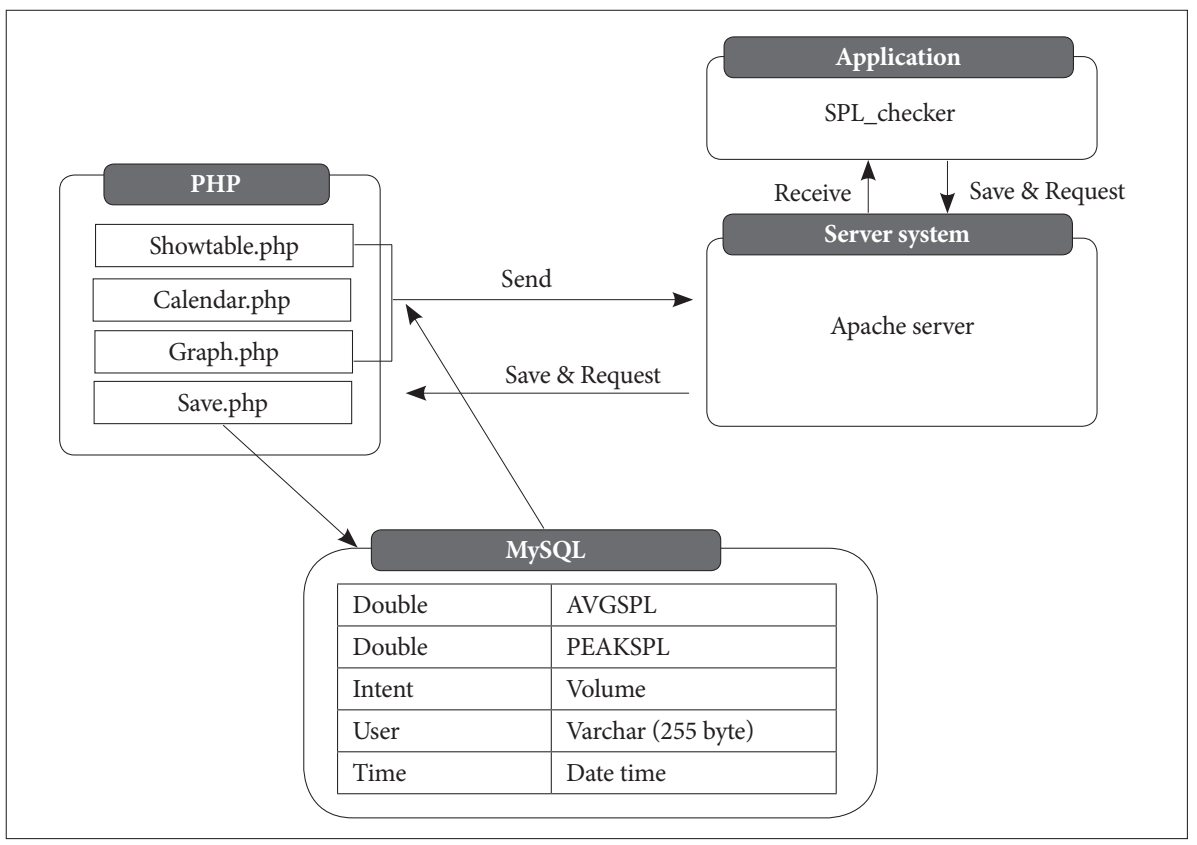

Figure 2. Server system. PHP: Hypertext Preprocessor, AVGSPL: average sound pressure level, PEAKSPL: peak sound pressure level. 
음압 강도를 정확하게 표현하는지 확인하였다. 즉, 음원 재생 시 스마트폰에 이어폰을 연결한 후 소음측정계(sound level meter)와 인공 귀 시뮬레이터(artificial ear simulator)에서 측 정한 값이 개발된 어플리케이션 실행 유무에 따라 혹은 어플리 케이션 자체에서 계산되어 보여지는 수치에 대해 일치하는지 확인하기 위해 실험실에서 시뮬레이션 기법으로 음압 강도를 측정하였다. 구체적으로, 소음측정계(type \#2250, Brüel \& Kjær, Nærum, Denmark)와 1/2 인치 마이크로폰(type \#4192, Brüel \& Kjær)을 사용하여 이어폰(Xiaomi PISTON 3, Beijing, China)을 통해 나오는 음압 강도는 인공 귀 시뮬레이터(type \#4153, Bruiel \& Kjær)와 2 cc 커플러(type \#4946, Brüel \& $\mathrm{Kjær}$ )에 연결하였다(Yu et al., 2016). 더불어 스마트폰의 마이 크로 들어오는 외부 소음의 값이 정확하게 표현되는지 확인하 기 위해서는 소음측정계와 free-field용 $1 / 2$ 인치 마이크로폰 (type \#4189, Brüel \& Kjær)을 적용하였다.

일반적으로 총 16 단계(0 15 볼륨)로 구성된 스마트폰에서 볼 륨을 한 단계씩 증가함에 따라 이어폰을 통해 출력되는 소리의 강도가 소음측정계를 통하여 측정되는 값과 일치하는지 확인하 였다. 측정 음원은 온라인 음악 서비스 제공자인 멜론(www. melon.com)에서 2016년 2 3월 1달간의 인기 순위를 기준으로 발라드와 댄스 음악을 각각 1곡씩 선정하였다. 음악 재생 동안 소음측정계와 인공 귀 시뮬레이터에서 직접 측정, 어플리케이 션 실행 중 소음측정계와 인공 귀 시뮬레이터에서 측정, 어플 리케이션에서 측정된 수치 적용 시 평균 강도( $(\mathrm{Zeq})$ 와 소리의 최대 강도(LCpeak)가 $\pm 5 \mathrm{~dB}$ 이내로 일치하였다(Figure 3A). 또한 외부 소음의 측정 값이 소음측정계와 개발된 어플리케이션 을 통한 스마트폰 마이크에서 측정값과 차이가 있는지 5 개의 장 소에서 확인하였고 $\pm 5 \mathrm{~dB}$ 이내로 일치성을 보였다(Figure $3 \mathrm{~B}$ ).

\section{RESULTS}

\section{어플리케이션 시스템}

\section{화면 구성}

개발된 어플리케이션의 초기 화면은 크게 5 가지(image bar, option bar, graph view, seek bar, text view)로 구분되며 작동 및 정지 화면의 예는 Figure 4와 같다. Image bar는 어플리케 이션의 서비스에서 음량 데이터의 측정 여부를 이미지로 보여 주는 역할을 하며, 어플리케이션을 사용하여 음악을 청취할 경 우 빨간 버튼, 음악 정지 시 하얀 버튼으로 작동하도록 개발하 였다. Option bar는 그래프를 출력하기 위한 기준을 선택하도 록 하는 역할을 하며 시간별/일별/주별/월별 그래프를 출력할 수 있도록 하였다. 또한 현재 측정 중인 평균 음량 데이터를 이
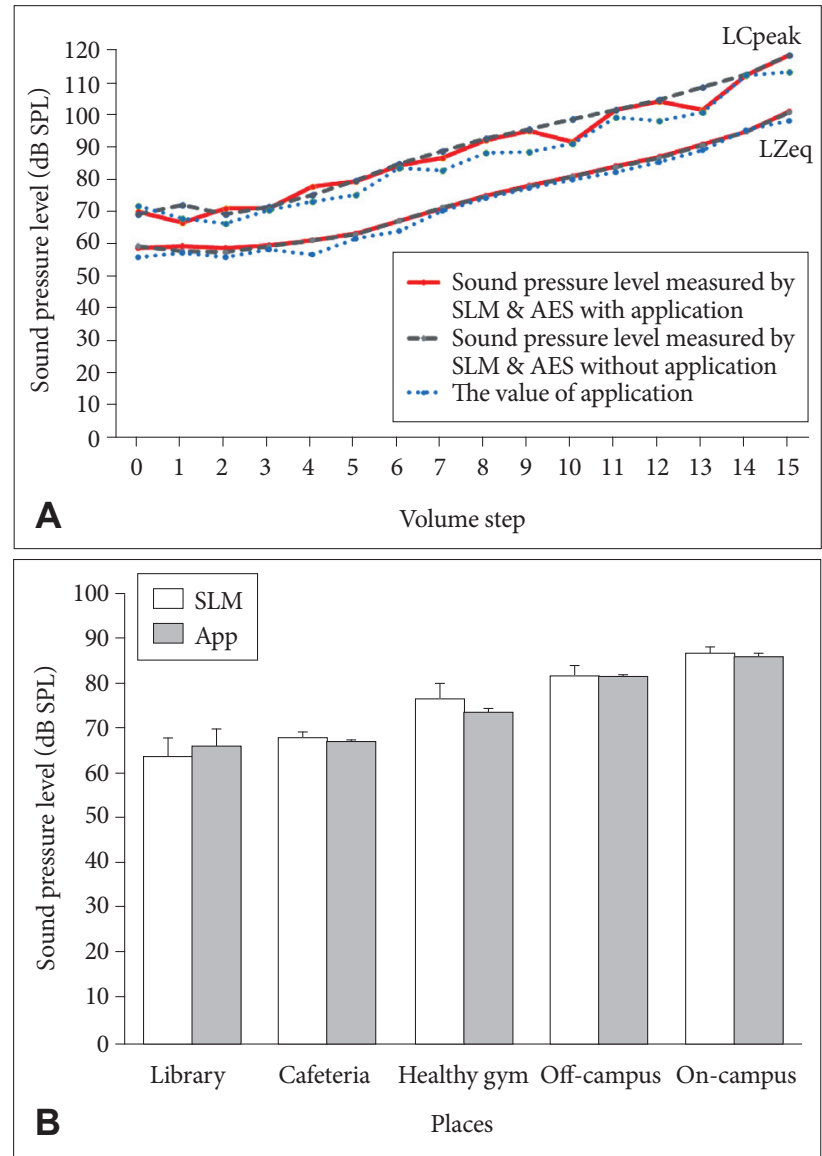

Figure 3. Results of accuracy for application microphone. A: Conformity of measurements between application's microphone and AES with 2cc coupler using SLM. Red curve represents sound pressure levels by AES and SLM when application running as a function of volume steps. Grey curve is sound pressure levels under same condition without running of the developed application. Blue dotted line is sound pressure levels from only the application without AES and SLM. B: Conformity of measurements between smartphone external microphone and SLM under application running. AES: artificial ear simulator, SLM: sound level meter.

퀄라이저로 출력하도록 하는 역할을 하는 graph view는 음량 의 크기 및 청취 환경에 맞게 작동되며, 안드로이드용 스마트폰 의 볼륨 단계 값이 실시간으로 변화됨에 따라 달리 출력하도록 seek bar를 사용하였다. 측정 데이터를 화면상에 표시하여 사용 자가 현재의 청취 상태에 대해 쉽게 이해할 수 있도록 text view 를 추가하였고, 평균 청취 음량, 최고 청취 음량, 볼륨 단계, 주 변 배경 소음 강도를 문자로 표기하였다.

\section{Graphical view(시간별/일별/주별/월별 분석 그래프)}

어플리케이션을 작동하여 누적된 청취 음량의 평균 및 최고 청취 음량을 시간별, 일별, 주별, 월별로 사용자가 이해하기 쉽도록 그래프로 제시하였다. 시간별 데이터의 경우, 사용자의 생활패턴을 고려하여 1일을 기준으로 5:00:00 am부터 다음날 4:59:59 am까지 24시간을 1시간 단위로 총 24개의 막대 그래프 

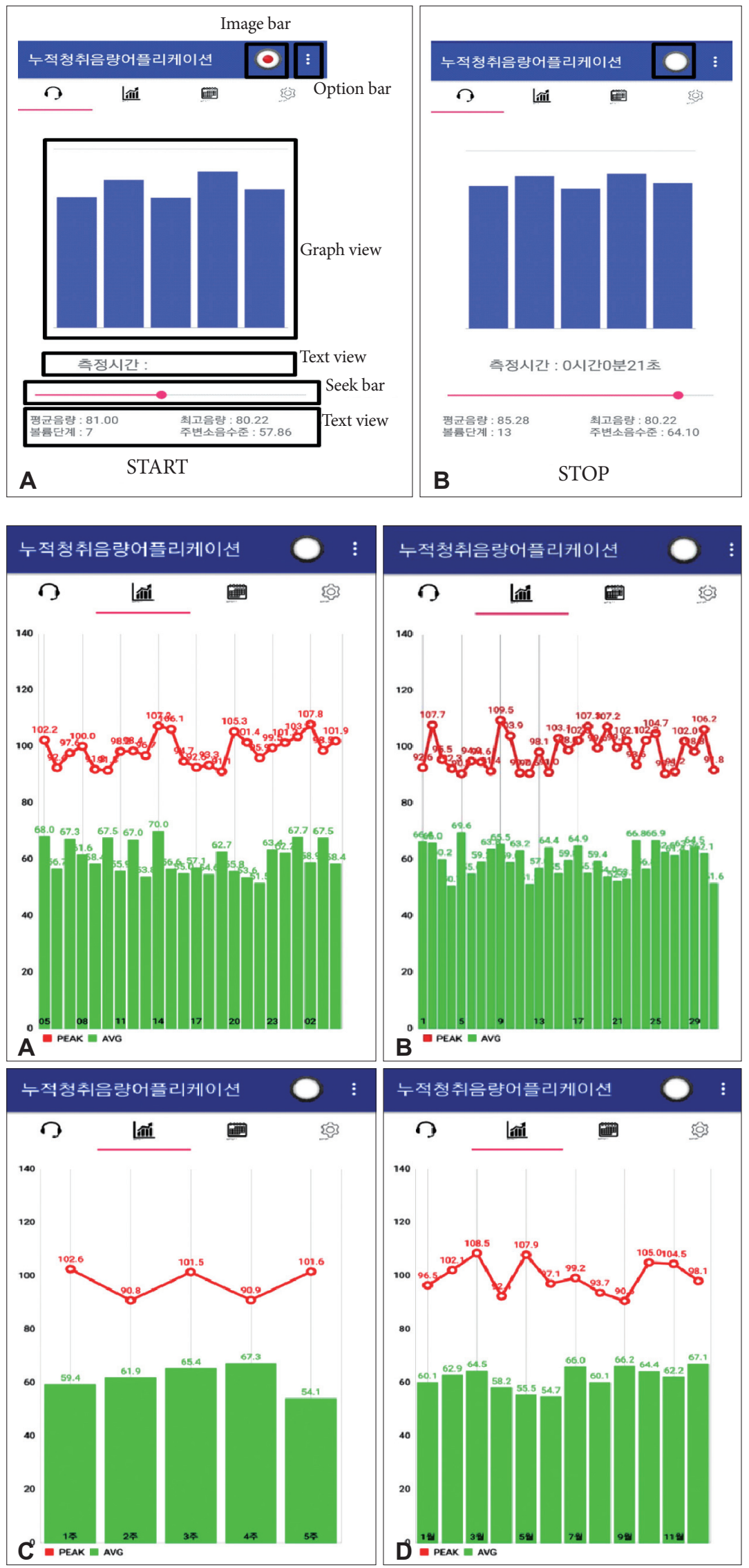
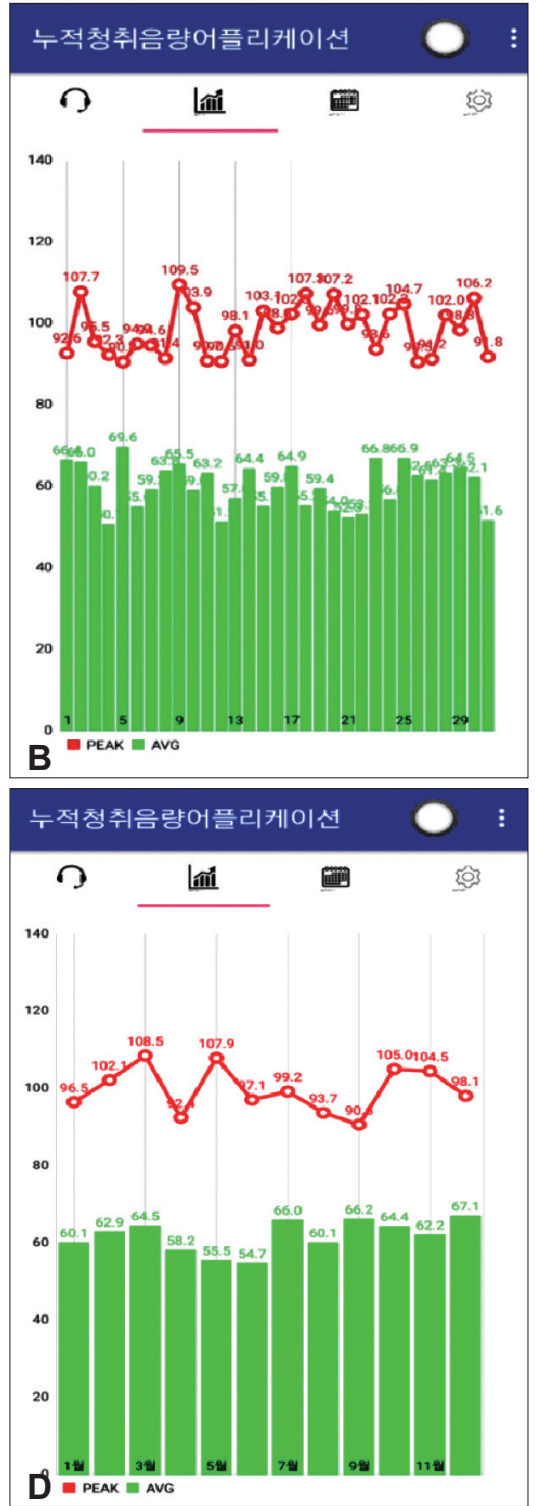

Figure 4. Measurement images of the developed application: (A) running image, (B) stop image.
Figure 5. Screen shot of graphical view: (A) time, (B) daily, (C) weekly, (D) monthly. Average sound pressure levels for bar graphs and maximum peak levels for curves. 
와 데이터를 제시하였고(Figure 5A), 일별 그래프에서는 매달 1 일부터 마지막 날까지 총 31 개의 데이터를 시간별과 같은 방식 으로 보여주도록 하였다(Figure 5B). 주별 데이터는 매달 1주차 부터 마지막 주까지 주별 평균 데이터를 제시하였고(Figure $5 \mathrm{C})$, 월별은 매년 1 월에서 12 월에 해당하는 각 달의 평균 음량 을 동일한 방식으로 보여주도록 하였다(Figure 5D).

Calendar view(달력 화면)와 Setting view(계정)

달력 표기 방식을 통해 해당 날짜를 기준으로 하루 동안 청 취한 평균 음량 강도를 분석하여 3 가지의 색으로 달리 제시함으 로써 사용자가 본인의 청취 습관을 한눈에 확인할 수 있도록 구 성하였다. 초록색은 0 50 dB SPL 이하의 강도로 안전한 청취 음량에서 음악을 청취하였음을 의미하며, 노란색은 $51 ~ 85 \mathrm{~dB}$ SPL 미만으로(경고 수준), 빨간색은 $85 \mathrm{~dB} \mathrm{SPL}$ 이상으로(위험 수준) 음악을 청취하였음을 컬러코딩으로 달리 제시하여 사용자 가 개인별 청취 패턴을 스스로 파악하도록 하였다(Figure 6A). 계 정에서는 사용자 개개인의 안드로이드에 연동되어있는 구글 계 정 정보를 불러와서, text view에 출력하도록 구성하였다(Figure $6 \mathrm{~B}$ ).

\section{서버 시스템}

데이터 저장 결과 화면은 클라이언트 시스템에서 전송한 데

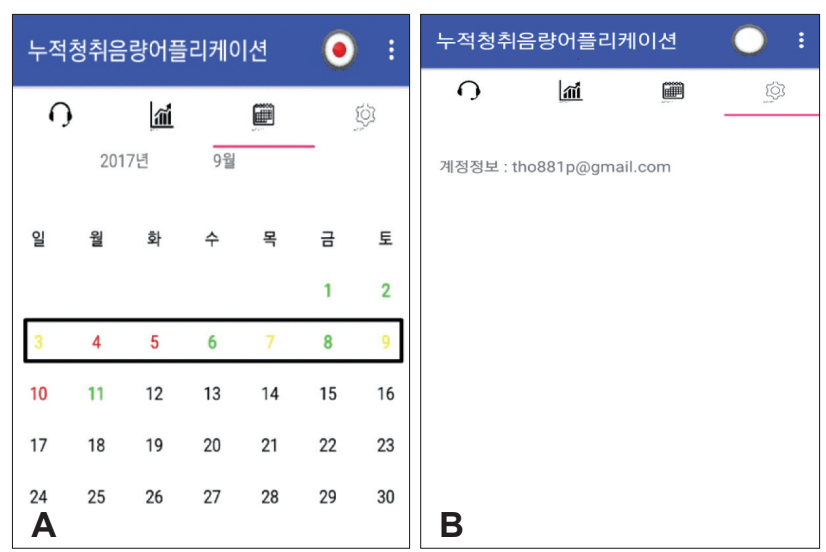

Figure 6. Screen shot of calendar view (A) and setting view (B).
이터의 평균 청취 음량, 최고 청취 음량, 볼륨 단계, 사용자 계 정, 시간 데이터를 전송 주기인 5초에 한번씩 save.php 페이지를 통해 데이터베이스 테이블 구조에 맞게 저장하였다(Figure 7).

\section{DISCUSSIONS}

현대사회에서 과도한 휴대용 음향기기의 사용으로 인한 청 소년 및 성인들의 소음성 난청 유발 위험성에 대한 경고는 이미 많은 논문에서 증명되었다(Kujawa \& Liberman, 2009). 본 논 문에서는 스마트폰 MP3 플레이어와 이어폰을 사용하여 음악 을 청취하는 사람들의 실제 선호 청취음량 평균 강도 및 최고 강도에 대한 정보를 추적 조사하고, 개개인의 생활패턴에 따른 분석을 하고자 누적 청취 음량을 측정할 수 있는 안드로이드용 스마트폰 어플리케이션을 개발하였다.

\section{모의 실험 적용}

개발된 어플리케이션의 오작동 여부를 확인하기 위해 3 명의 대학생을 대상으로 약 2주간 모의실험을 시행하였다. 연구대상 자들은 실험 참여 전 연구동의서를 읽고 서명하였으며, 모든 연 구 절차는 한림대학교 생명윤리위원회에서 승인되었다(HIRB2016-060). 연구대상자에게 평소 생활습관과 동일하게 음악을 청취하도록 요청하였다. 그러나 평소 생활 습관과 달리 주변 배 경 소음이 너무 조용하거나(예를 들어, 도서관, 조용한 길거리 등) 혹은 너무 시끄러운 장소(예를 들어, 헬스장, 카페, 대중교 통 이용 시)에서 음악을 청취할 경우에는 스마트폰에 내장된 메모창에 청취 시간 및 배경 소음 정보에 대해 기록하도록 하 였다. 모의 실험에 대한 자료는 하루 동안 청취한 평균 청취 음 량 강도를 시간대별, 일별로 분석하여 음악 청취 시간 및 휴식 시간을 확인하였다. 특히 어플리케이션이 작동 중일 때(이어폰 을 통한 음악 청취 시), 작동을 하지 않을 때(이어폰을 통한 음 악 청취가 아닐 시)를 분별하여 측정되고 있는지, 측정된 데이 터가 실시간으로 서버 시스템에 전송되는지 꼼꼼히 확인하였다. 개발된 어플리케이션을 통하여 측정된 하루 동안의 평균 음압 수준은 연구대상자별로 68.02, 61.64, 63.10 LZeq를 기록하였

Figure 7. Screen shot of the server sys-

\begin{tabular}{|c|c|c|c|c|c|c|}
\hline I AUGSPL & I PEAKSPL & I VOLUM & & user & I time & \\
\hline : 74.85287123 & | 75.00532013 & i & 5 I & dlgoal1928Egmail.com & | 2016-08-01 & $68: 37: 31$ \\
\hline : 74.10622304 & | 75.19143091 & i & 5 & dlgoal1928Egmail.com & : 2016-08-01 & $08: 37: 36$ \\
\hline : 71.84250813 & I 80.9430609 & $\mathbf{i}$ & $6 \mathrm{i}$ & dlgoal1928egmail.com & : 2016-08-01 & $08: 37: 45$ \\
\hline : 77.49592885 & | 82.86107737 & I & $6 \mathrm{I}$ & dlgoal1928egmail.com & : 2016-08-01 & $08: 37: 51$ \\
\hline | 83.24222413 & 84.85114489 & $\mathbf{I}$ & 6 & dlgoal1928Egmail.com & I 2016-08-01 & $08: 37: 56$ \\
\hline | 77.02521811 & | 87.42987659 & $\mathbf{I}$ & 6 & dlgoal1928Egmail.com & 2016-08-01 & $08: 38: 01$ \\
\hline | 80.45263432 & | 87.64634891 & $\mathbf{I}$ & $\mathbf{7}$ & dlgoal1928Egmail.com & I 2016-08-01 & $08: 38: 06$ \\
\hline | 72.97930974 & | 88.42373733 & i & 7 & dlgoal1928Egmail.com & 2016-08-01 & $08: 38: 11$ \\
\hline | 73.30160868 & | 89.59190962 & $\mathbf{I}$ & 7 & dlgoal1928Egmail.com & I 2016-08-01 & $08: 38: 16$ \\
\hline I 75.46576557 & | 90.54657675 & i & 7 & dlgoal1928Egmail.com & 2016-08-01 & $08: 38: 21$ \\
\hline
\end{tabular}


다. 주요 시간별 평균 청취 음량에 대한 분석은 오후 2시의 평 균 청취 음량 강도는 $76.64 \mathrm{~dB} \mathrm{SPL}$, 오후 3시 $64.06 \mathrm{~dB} \mathrm{SPL}$, 오후 6시 $62.60 \mathrm{~dB}$ SPL, 오후 8시 $73.12 \mathrm{~dB}$ SPL, 오후 9시 $77.09 \mathrm{~dB}$ SPL로 나타났으며, 예상 외로 조용한 밤인 오후 9시 에 가장 높은 청취 음량을 보였다. 이는 카페 등의 배경 소음이 있는 상황에서 강의 후 과제 수행할 때 청취한 음량으로 분석 되었다. 모의 실험 동안 어플리케이션의 오작동 여부는 특별히 발생되지 않았다.

\section{추후 보완사항 및 임상적 적용}

지금까지 개발된 어플리케이션의 기능들은 사용 시 오작동 여부 등 특별한 문제가 발생되지는 않았지만, 추후 스마트폰 사용 시간이 가장 많은 청소년 및 젊은 성인을 대상으로 임상 적용 연구를 시행하고, 추가 구성되어야 할 기능들을 더 구상해 야 하겠다. 또한 현재 제시되고 있는 소음성 난청의 국제기준들 을 구체적으로 분석하여 본 어플리케이션의 기능에 기준에 따 른 소음성난청 정도를 예측하도록 추가 적용해야 하겠다. 후속 연구에서는 이어폰 종류에 따른 표준화된 어플리케이션이 실 행될 수 있어야 하겠다. 즉, 현재 개발된 어플리케이션은 가장 대중성이 높은 샤오미사의 이어버드 타입으로 고정하여 오차 값을 보정하여 실제 귀에서 듣는 음압을 객관화시켰다. 그러나 이는 이어폰의 종류 및 사양의 차이점이 발생하면 개발된 해당 어플리케이션이 실행될 때마다 커플링 이슈로 추가적인 보정이 필요하다. 궁극적으로는 청력 손실을 유발할 수 있는 강도의 유희적 소음에 노출되는 개개인의 실제 생활패턴 및 청취 습관 을 파악하고, 적절한 경고 및 권고사항을 제시하여야겠다. 즉, 데이터를 바탕으로 청취 습관을 파악해서 개인별 유희적 소음 노출 패턴을 분석하고, 사용자 스스로가 행동수정을 통한 소음 성 난청의 발생 및 노인성 난청의 조기화를 예방하는 데 있어 도움을 줄 수 있는 실질적인 도구로 자리매김하고자 한다.

중심 단어 : 스마트폰 어플리케이션·음압 수준·이어폰· 소음성 난청·안드로이드.

\section{Acknowledgments}

본 논문은 미래창조과학부와 한국연구재단의 이공계 신진연구자 지원사업(NRF2017R1A1A05001299)으로부터 연구비를 지원받아 수행되었습니다.

\section{REFERENCES}

Axelsson, A. \& Hamernik, R. P. (1987). Acute acoustic trauma. Acta Otolaryngologica, 104(3-4), 225-233.

Basner, M., Babisch, W., Davis, A., Brink, M., Clark, C., Janssen, S., et al. (2014), Auditory and non-auditory effects of noise on health. Lancet, 383(9925), 1325-1332.

Danhauer, J. L., Johnson, C. E., Byrd, A., DeGood, L., Meuel, C., Pecile, A., et al. (2009). Survey of college students on iPod use and hearing health. Journal of the American Academy of Audiology, 20(1), 5-27.

Fligor, B. J. \& Cox, L. C. (2004). Output levels of commercially available portable compact disc players and the potential risk to hearing. Ear and Hearing, 25(6), 513-527.

Hodgetts, W. E., Rieger, J. M., \& Szarko, R. A. (2007). The effects of listening environment and earphone style on preferred listening levels of normal hearing adults using an MP3 player. Ear and Hearing, 28(3), 290-297.

Keppler, H., Dhooge, I., \& Vinck, B. (2015). Hearing in young adults. Part I: The effects of attitudes and beliefs toward noise, hearing loss, and hearing protector devices. Noise and Health, 17(78), 237-244.

Kim, K. S. (2003). Industrial audiology and occupational hearing loss. Korean Journal of Audiology, 7(1), 3-14.

Kujawa, S. G. \& Liberman, M. C. (2009). Adding insult to injury: Cochlear nerve degeneration after "temporary" noise-induced hearing loss. The Journal of Neuroscience, 29(45), 14077-14085.

National Institute of Occupational Safety and Health (NIOSH). (1998). Criteria for a Recommended Standard: Occupational Noise Exposure. (pp.1-126). Cincinnati, OH: Department of Health and Human Services.

Ryan, A. F., Kujawa, S. G., Hammill, T., Le Prell, C., \& Kil, J. (2016). Temporary and permanent noise-induced threshold shifts: A review of basic and clinical observations. Otology and Neurotology, 37(8), e271-e275.

Saunders, J. C., Dear, S. P., \& Schneider, M. E. (1985). The anatomical consequences of acoustic injury: A review and tutorial. The Journal of the Acoustical Society of America, 78(3), 833-860.

Spieth, W. \& Trittipoe, W. J. (1958). Intensity and duration of noise exposure and temporary threshold shifts. The Journal of the Acoustical Society of America, 30(8), 710.

Williams, W. (2005). Noise exposure levels from personal stereo use. International Journal of Audiology, 44(4), 231-236.

Yu, J., Lee, D., \& Han, W. (2016). Preferred listening levels of mobile phone programs when considering subway interior noise. Noise and Health, 18(80), 36-41.

Zogby International. (2016, November 5). Survey of Teens and Adults about the Use of Personal Electronic Devices and Head Phones 2006. American Speech-Language-Hearing Association. Retrieved from https://www. asha.org/Buds/Survey-About-the-Use-of-Personal-Electronic-Deviceswith-Headphones/. 